\title{
Quality Parameters, Nutrient Content and Uptake as Influenced by INM in Wheat (Triticum aestivum L.) under Saline and Non-Saline Irrigation Water
}

\author{
Sunil Kumar ${ }^{1}$, Satyavan $^{1}$, Ramprakash $^{2 *}$ and Devender Sihag ${ }^{3}$ \\ ${ }^{1}$ Department of Agronomy, ${ }^{2}$ Department of Soil Science, C C S H AU, Hisar-125004, \\ Haryana, India \\ ${ }^{3}$ Quality Control Laboratory Fertilizer, Hisar-125004, India \\ *Corresponding author
}

\begin{tabular}{|l|}
\hline K e y w or d s \\
$\begin{array}{l}\text { Wheat, Quality } \\
\text { parameters, Nutrient } \\
\text { content and uptake, } \\
\text { Saline water, Canal water, } \\
\text { Integrated nutrient } \\
\text { management }\end{array}$ \\
\hline Article Info \\
\hline $\begin{array}{l}\text { Accepted: } \\
\text { 07 April } 2018 \\
\text { Available Online: } \\
\text { 10 May } 2018\end{array}$ \\
\hline
\end{tabular}

\section{Introduction}

Wheat (Triticum aestivum L.) is the second most important staple food crop at global scenario after rice. Quality parameters of flour viz., colour, appearance etc. are very much important for preparation of final products like bread, chapatti, biscuits etc. In the present investigation various physico-chemical parameters like sedimentation value, protein content and hectoliter weight were determined to study the impact of treatments. Sedimentation value gives an idea of the gluten strength. End use quality of wheat is influenced by quantity and quality of gluten proteins and latter is responsible for selection 
of wheat varieties for different products (Joppa, 1975). In wheat grains, the sedimentation value normally range from 21 to $47 \mathrm{ml}$ with a mean value of $34 \mathrm{ml}$ (Misra and Gupta, 1995).Protein content is the principal factor determining baking properties of wheat flour. Singh and Paliwal (1986) reported that protein content ranged from 8.82 to 15.85 per cent, in T. aestivum while protein in Mexican wheat flour ranged from 9.6 to 11.0 per cent. Hence, it was realized to integrate bio-fertilizers, chemical fertilizers and vermicompost with an aim to investigate the impact on quality parameters and nutrient availability to wheat crop under both saline water and non-saline irrigation water.

\section{Materials and Methods}

Integrated nutrient management studies in wheat crop under saline and non-saline irrigation water were conducted during rabi seasons of 2011-2012 and 2012-2013 at Research Farm, Department of Soil Science, of Chaudhary Charan Singh, Haryana Agricultural University, Hisar. Hisar is situated in the sub-tropics at $29^{\circ} 10^{\prime} \mathrm{N}$ latitude and $75^{\circ} 46^{\prime} \mathrm{E}$ longitudes at an elevation of 215.2 meter above mean sea level in Haryana, India. The soil was sandy loam in texture, low in organic carbon and available nitrogen, medium in available phosphorus and high in available potassium. WH-711 was used as seedling material, vermicompost was used as organic source and urea, diamonium phosphate and zinc sulphate were used as chemical fertilizers at the recommended dose (RDF) as per the package and practices of CCSHAU. WH-711 seeds were inoculated with Azotobacter ST3 and Pseudomonas P36 during both the years. The experiment comprised of two levels of quality of irrigation water viz., canal (non-saline) water and saline water $(8-10 \mathrm{dS} / \mathrm{m})$ and four inoculation and vermicompost treatments viz., no inoculation (control),vermicompost @ 5t/ha, Azotobacter
ST3 + Pseudomonas $\mathrm{P} 36$ and Azotobacter ST3 + Pseudomonas P36 + vermicompost @ 5 t/ha in main plots and three levels of fertilizer viz., 75,100 and $125 \%$ RDF in sub-plots. The 24 treatment combinations were tested in split plot design replicated thrice. Grain samples were tested for hectolitre weight with the help of hectoliter weight instrument available in the Wheat Quality Laboratory of CCS HAU, Hisar. Sedimentation value was determined by the method of Axford et al., (1979). Protein content in grain was calculated by multiplying the percentage of nitrogen ingrains with 6.25. To determine total nitrogen, phosphorus and potassium in plant samples, $0.2 \mathrm{~g}$ of dry material of grains and $0.5 \mathrm{~g}$ straw were digested with diacid mixture of $\mathrm{H}_{2} \mathrm{SO}_{4}$ and $\mathrm{HClO}_{4}$ of $9: 1(\mathrm{v} / \mathrm{v})$ ratio. After digestion, the volume was raised to $50 \mathrm{ml}$ with distilled water. This digested material was stored in plastic bottles after filtering through Whatman filter paper no.42 for further analysis. Nitrogen in plant samples was determined from the digested material by using Colorimetric (Nessler's reagent) method (Lindner, 1944). Phosphorus in plant samples was determined from the digested material by using Vanadomolybdo phosphoric yellow color method (Koenig and Johnson, 1942).Potassium in plant samples was determined from the digested material by using flame photometer (directly). The data on quality parameters namely hectolitre weight, sedimentation value, protein content and nutrient content and uptake were analyzed using OP Stat software at 5\% level of significance.

\section{Results and Discussion}

\section{Quality parameters}

\section{Hectolitre weight}

The data presented in Table 1 revealed that there were no significant differences among 
the treatments (quality of irrigation water, levels of fertilizer, inoculation and vermicompost) with respect to hectolitre weight during both the years. Hectolitre weight ranged from 75.55 to $76.38 \mathrm{~kg} / \mathrm{hl}$ during first year and 75.49 to $76.33 \mathrm{~kg} / \mathrm{hl}$ in second year. Similar findings were reported by Fana et al., (2012) and Bulut (2013).

\section{Sedimentation value $(\mathrm{ml})$}

Quality of irrigation water and levels of fertilizer did not significantly affect the sedimentation value during both the years. In line with the findings, non-significant effect of salinity (Zheng et al., 2009 and Naserian et al., 2014) and levels of fertilizer (Knapowski et al., 2009) has been reported in previous studies. Although sedimentation values were higher in canal water and $125 \% \mathrm{RDF}$, this may be due to decrease in the gluten content at higher salinity and lower fertilizer levels. The findings are in agreement with that of Francois et al., (1986) who observed diminishing sedimentation values due to salinity stress. However, inoculation and vermicompost treatments differed significantly with respect to sedimentation value. Maximum sedimentation value was recorded in Azotobacter ST3 and Pseudomonas P36 + vermicompost @ 5 t/ha (31.31, $31.20 \mathrm{ml})$ while minimum was recorded in no inoculation (28.33, $28.61 \mathrm{ml})$ during 2011-12 and 2012-13, respectively. In line with the findings, Ram et al., (2014) reported maximum sedimentation value in $\mathrm{GM}+$ FYM+ Biofertilizers treatment $(43.36 \mathrm{ml})$ and minimum in control (no inoculation, 38.20 $\mathrm{ml}$ ). Similar results were obtained by Konvalina et al., (2009) and Davari et al., (2012).

\section{Protein content $(\%)$}

Protein content of wheat grains differed significantly in all the treatments viz., quality of irrigation water, levels of fertilizer and inoculation and vermicompost during both the years (Table 1). Canal water treatment resulted in higher protein content as compared to saline water during 2011-12 (12.23, $11.11 \%)$ as well as $2012-13(12.13,10.94 \%)$, respectively. Likewise, reduction in protein content due to salinity was reported by Kumar (2000), Tammam et al., (2008) and Datta et al., (2009). Among the inoculation and vermicompost treatments, Azotobacter ST3 and Pseudomonas P36+ vermicompost @ 5 t/ha $(11.85,11.76 \%)$ was found superior with respect to protein content as compared to no inoculation $(11.47,11.24 \%)$ during both the years, respectively, while it was at par with vermicompost @ 5t/ha. In line with the findings, Ram et al., (2014) reported maximum protein content in GM + FYM+ Biofertilizer treatment $(9.01 \%)$ and minimum in control (no inoculation, 7.08\%).Application of fertilizer@125\% RDF resulted in highest protein content $(11.88,11.82 \%)$ followed by $100 \%$ RDF $(11.78,11.64 \%)$ while lowest was recorded in $75 \%$ RDF $(11.36,11.15 \%)$ during 2011-12 and 2012-13, respectively. Likewise, Kumar (2000) and Sharma et al., (2013) reported significant increase in protein content as the recommended dose of fertilizer increased. The increase of protein content (wheat grain) in different treatments might be due to increased nitrogen uptake as influenced by the use of vermicompost and fertilizers.

\section{Chemical analysis}

\section{Nitrogen content $(\%)$ and its uptake (kg/ha) by grain and straw}

Data presented in Table 2 revealed that $\mathrm{N}$ content in grain and straw, $\mathrm{N}$ uptake by grain and straw and total $\mathrm{N}$ uptake varied significantly among different treatments (quality of irrigation water, inoculation and vermicompost and levels of fertilizer) during both the years. Under quality of irrigation 
water, canal water treatment resulted insignificantly higher $\mathrm{N}$ content in grain $(1.954,1.941 \%)$ as compared to saline water (1.777, 1.749\%) during 2011-12 and 2012-13, respectively. Similar trend was observed for $\mathrm{N}$ content in straw, $\mathrm{N}$ uptake by grain and straw and total $\mathrm{N}$ uptake during both the years of study. The results of current studies are in conformity with Kumar (2000), Hussain et al., (2014) and Saleh et al., (2015). The decrease in $\mathrm{N}$ uptake may be due to accumulation of $\mathrm{Na}^{+}$and $\mathrm{Cl}^{-}$under salinity stress (Alam, 1999). Low content of nitrogen ingrains due to low $\mathrm{N}$ uptake was due to limited synthesis of specific $\mathrm{N}$ compounds such as proline, glutamine and asparagine (Mansour, 2000 and Ashraf and Harris, 2004).

Under inoculation and vermicompost treatments, Azotobacter ST3 and Pseudomonas P36 + vermicompost @ 5 t/ha treatment resulted in significantly higher $\mathrm{N}$ content ingrain and straw followed by vermicompost @ 5t/ha and minimum was observed in no inoculation during both the years. Similar trend was observed for $\mathrm{N}$ uptake by grain, $\mathrm{N}$ uptake by straw and total $\mathrm{N}$ uptake. Current findings corroborate with those of Devi et al., (2011), Davari et al., (2012), Sharma et al., (2013), Shishehbor et al., (2013), Ram et al., (2014) and Hussain et al., (2016).

The higher nutrient uptake with organic manure and biofertilizers might be attributed to solublization of native nutrients by microorganisms, chelation of complex intermediate organic molecules produced during decomposition of added organic manures, their mobilization and accumulation of different nutrients in different plant parts. The results are in agreement with the findings of Sharma et al., (2013).

Among various fertilizer treatments, $125 \%$ $\mathrm{RDF}$ treatment recorded maximum $\mathrm{N}$ content in grain and straw followed by $100 \%$ RDF and minimum was observed in $75 \%$ RDF during both the years. Similar trend was observed for $\mathrm{N}$ uptake by grain and straw and total $\mathrm{N}$ uptake. The increased content and uptake of $\mathrm{N}$ and $\mathrm{P}$ was due to added supply of nutrients and well developed root system resulting in better absorption of water and nutrients. In line with the findings, Laghari et al., (2010), Chesti et al., (2013) and Sharma et al., (2013) reported increase in $\mathrm{N}$ uptake as the levels of fertilizer increased.

\section{Phosphorous content (\%) and its uptake (kg/ha) by grain and straw}

Phosphorous content in grain and straw, $\mathrm{P}$ uptake by grain and straw and total $\mathrm{P}$ uptake varied significantly among quality of irrigation water, inoculation and vermicompost and different levels of fertilizer treatments during both the years (Table 3). Under quality of irrigation water, canal water treatment resulted in significantly higher $\mathrm{P}$ content in grain $(0.266,0.256 \%)$ as compared to saline water $(0.230,0.224 \%)$ during 2011 12 and 2012-13, respectively.

Similar trend was observed for $\mathrm{P}$ content in straw, $\mathrm{P}$ uptake by grain and straw and total $\mathrm{P}$ uptake during both the years of investigation. The results of present studies are in conformity with Kumar (2000), Yadav et al., (2015) and Hussain et al., (2014). Soil salinity significantly reduces plant $\mathrm{P}$ uptake because phosphate ions precipitate with $\mathrm{Ca}^{+}$ions (Bano and Fatima, 2009).

Under inoculation and vermicompost treatments, Azotobacter ST3 and Pseudomonas P36 + vermicompost@ 5 t/ha treatment resulted in significantly higher $\mathrm{P}$ content in grain and straw followed by vermicompost @ 5t/ha and minimum was observed in no inoculation during both the years. Similar trend was observed for P uptake by grain and straw and total $\mathrm{P}$ uptake. 
Table.1 Effect of saline water and different nutrient management practices on sedimentation value, protein content and hectolitre weight of wheat

\begin{tabular}{|c|c|c|c|c|c|c|}
\hline \multirow[t]{2}{*}{ Treatments } & \multicolumn{2}{|c|}{$\begin{array}{c}\text { Sedimentation } \\
\text { value } \\
(\mathrm{ml})\end{array}$} & \multicolumn{2}{|c|}{$\begin{array}{l}\text { Protein content } \\
\qquad(\%)\end{array}$} & \multicolumn{2}{|c|}{$\begin{array}{l}\text { Hectolitre } \\
\text { weight } \\
\text { (kg/hl) }\end{array}$} \\
\hline & 2011-12 & 2012-13 & $\begin{array}{c}2011- \\
12\end{array}$ & $\begin{array}{l}2012- \\
13\end{array}$ & $\begin{array}{l}2011- \\
12\end{array}$ & $\begin{array}{c}2012- \\
13\end{array}$ \\
\hline \multicolumn{7}{|l|}{ Quality of irrigation water } \\
\hline Canal water & 30.11 & 30.40 & 12.23 & 12.13 & 76.37 & 76.33 \\
\hline Saline water & 29.63 & 29.85 & 11.11 & 10.94 & 75.66 & 75.56 \\
\hline SEm \pm & 0.16 & 0.21 & 0.04 & 0.04 & 0.58 & 0.62 \\
\hline CD at $5 \%$ & NS & NS & 0.11 & 0.11 & NS & NS \\
\hline \multicolumn{7}{|l|}{ Inoculation and vermicompost } \\
\hline $\begin{array}{l}\text { Inoculation (Azotobacter ST3 \&Pseudomonas P 36) + vermicompost } \\
\text { @5t/ha }\end{array}$ & 31.31 & 31.20 & 11.85 & 11.76 & 76.38 & 76.33 \\
\hline Inoculation (Azotobacter ST3 \&Pseudomonas P 36) & 29.53 & 29.83 & 11.60 & 11.47 & 75.80 & 75.73 \\
\hline Vermicompost@5t/ha & 30.30 & 30.85 & 11.77 & 11.68 & 76.34 & 76.24 \\
\hline No inoculation & 28.33 & 28.61 & 11.47 & 11.24 & 75.55 & 75.49 \\
\hline SEm \pm & 0.23 & 0.30 & 0.05 & 0.05 & 0.83 & 0.88 \\
\hline CD at $5 \%$ & 0.69 & 0.90 & 0.16 & 0.15 & NS & NS \\
\hline \multicolumn{7}{|l|}{ Fertilizers } \\
\hline $75 \%$ RDF & 29.71 & 29.99 & 11.36 & 11.15 & 75.85 & 75.89 \\
\hline $100 \%$ RDF & 29.80 & 30.11 & 11.78 & 11.64 & 76.07 & 75.95 \\
\hline $125 \%$ RDF & 30.10 & 30.28 & 11.88 & 11.82 & 76.13 & 76.00 \\
\hline SEm \pm & 0.19 & 0.22 & 0.06 & 0.06 & 0.95 & 0.82 \\
\hline CD at $5 \%$ & NS & NS & 0.17 & 0.16 & NS & NS \\
\hline
\end{tabular}


Table.2 Effect of saline water and different nutrient management practices on nitrogen content and its uptake by wheat crop

\begin{tabular}{|c|c|c|c|c|c|c|c|c|c|c|}
\hline \multirow[t]{2}{*}{ Treatments } & \multicolumn{2}{|c|}{$\begin{array}{c}\mathbf{N} \text { content } \\
(\%) \\
\text { in grain }\end{array}$} & \multicolumn{2}{|c|}{$\begin{array}{c}\text { N content } \\
(\%) \\
\text { in straw }\end{array}$} & \multicolumn{2}{|c|}{$\begin{array}{c}\text { N uptake } \\
\text { (kg/ha) } \\
\text { by grain }\end{array}$} & \multicolumn{2}{|c|}{$\begin{array}{l}\text { N uptake } \\
\text { (kg/ha) by } \\
\text { straw }\end{array}$} & \multicolumn{2}{|c|}{$\begin{array}{l}\text { Total N } \\
\text { uptake } \\
\text { (kg/ha) }\end{array}$} \\
\hline & $\begin{array}{c}2011- \\
12\end{array}$ & $\begin{array}{c}2012- \\
13\end{array}$ & $\begin{array}{c}2011- \\
12\end{array}$ & $\begin{array}{c}2012- \\
13\end{array}$ & $\begin{array}{c}2011- \\
12\end{array}$ & $\begin{array}{c}2012- \\
13\end{array}$ & $\begin{array}{c}2011- \\
12\end{array}$ & $\begin{array}{c}2012- \\
13\end{array}$ & $\begin{array}{c}2011- \\
12\end{array}$ & $\begin{array}{c}2012- \\
13\end{array}$ \\
\hline \multicolumn{11}{|l|}{ Quality of irrigation water } \\
\hline Canal water & 1.954 & 1.941 & 0.607 & 0.582 & 99.90 & 90.40 & 46.59 & 38.61 & 146.49 & 129.01 \\
\hline Saline water & 1.777 & 1.749 & 0.546 & 0.512 & 72.74 & 69.82 & 34.50 & 27.34 & 107.23 & 97.16 \\
\hline SEm \pm & 0.005 & 0.006 & 0.004 & 0.003 & 0.91 & 0.76 & 0.44 & 0.37 & 1.14 & 0.94 \\
\hline CD at $5 \%$ & 0.016 & 0.017 & 0.011 & 0.011 & 2.77 & 2.31 & 1.34 & 1.13 & 3.46 & 2.85 \\
\hline \multicolumn{11}{|l|}{ Inoculation and vermicompost } \\
\hline $\begin{array}{l}\text { Inoculation (Azotobacter ST3 \&Pseudomonas P } \\
\text { 36) + vermicompost @5t/ha }\end{array}$ & 1.893 & 1.882 & 0.626 & 0.616 & 91.46 & 85.33 & 45.57 & 38.80 & 137.03 & 124.13 \\
\hline $\begin{array}{l}\text { Inoculation (Azotobacter ST3 \&Pseudomonas P } \\
\text { 36) }\end{array}$ & 1.854 & 1.834 & 0.579 & 0.531 & 85.59 & 78.06 & 40.39 & 31.22 & 125.98 & 109.28 \\
\hline Vermicompost @5t/ha & 1.880 & 1.866 & 0.584 & 0.550 & 88.12 & 81.83 & 41.39 & 33.52 & 129.51 & 115.35 \\
\hline No inoculation & 1.833 & 1.798 & 0.517 & 0.489 & 80.11 & 75.23 & 34.81 & 28.36 & 114.92 & 103.59 \\
\hline SEm \pm & 0.008 & 0.008 & 0.005 & 0.005 & 1.29 & 1.08 & 0.63 & 0.53 & 1.61 & 1.33 \\
\hline CD at $5 \%$ & 0.023 & 0.024 & 0.016 & 0.015 & 3.92 & 3.27 & 1.90 & 1.60 & 4.89 & 4.04 \\
\hline \multicolumn{11}{|l|}{ Fertilizers } \\
\hline $75 \% \mathrm{RDF}$ & 1.815 & 1.784 & 0.559 & 0.526 & 78.12 & 72.32 & 37.55 & 30.55 & 115.67 & 102.87 \\
\hline $100 \%$ RDF & 1.883 & 1.861 & 0.583 & 0.546 & 88.78 & 82.52 & 41.54 & 33.11 & 130.32 & 115.63 \\
\hline $125 \%$ RDF & 1.899 & 1.890 & 0.588 & 0.568 & 92.06 & 85.49 & 42.54 & 35.26 & 134.59 & 120.76 \\
\hline SEm \pm & 0.009 & 0.009 & 0.005 & 0.005 & 0.96 & 0.82 & 0.43 & 0.52 & 1.08 & 0.96 \\
\hline CD at $5 \%$ & 0.027 & 0.026 & 0.013 & 0.013 & 2.78 & 2.36 & 1.24 & 1.50 & 3.10 & 2.76 \\
\hline
\end{tabular}


Table.3 Effect of saline water and different nutrient management practices on phosphorus content and its uptake by wheat crop

\begin{tabular}{|c|c|c|c|c|c|c|c|c|c|c|}
\hline \multirow[t]{2}{*}{ Treatments } & \multicolumn{2}{|c|}{$\begin{array}{c}\text { P content } \\
(\%) \\
\text { in grain }\end{array}$} & \multicolumn{2}{|c|}{$\begin{array}{c}\text { P content } \\
(\%) \\
\text { in straw }\end{array}$} & \multicolumn{2}{|c|}{$\begin{array}{c}\text { P uptake } \\
\text { (kg/ha) } \\
\text { by grain }\end{array}$} & \multicolumn{2}{|c|}{$\begin{array}{l}\text { P uptake } \\
\text { (kg/ha) } \\
\text { by straw }\end{array}$} & \multicolumn{2}{|c|}{$\begin{array}{l}\text { Total P } \\
\text { uptake } \\
\text { (kg/ha) }\end{array}$} \\
\hline & $\begin{array}{c}2011- \\
12\end{array}$ & $\begin{array}{c}2012- \\
13\end{array}$ & $\begin{array}{c}2011- \\
12\end{array}$ & $\begin{array}{c}2012- \\
13\end{array}$ & $\begin{array}{c}2011- \\
12\end{array}$ & $\begin{array}{c}2012- \\
13\end{array}$ & $\begin{array}{c}2011- \\
12\end{array}$ & $\begin{array}{c}2012- \\
13\end{array}$ & $\begin{array}{c}2011- \\
12\end{array}$ & $\begin{array}{c}2012- \\
13\end{array}$ \\
\hline \multicolumn{11}{|l|}{ Quality of irrigation water } \\
\hline Canal water & 0.266 & 0.256 & 0.104 & 0.098 & 13.61 & 11.94 & 7.94 & 6.49 & 21.55 & 18.43 \\
\hline Saline water & 0.230 & 0.224 & 0.086 & 0.082 & 9.44 & 8.96 & 5.41 & 4.40 & 14.85 & 13.36 \\
\hline SEm \pm & 0.001 & 0.001 & 0.000 & 0.001 & 0.14 & 0.11 & 0.06 & 0.05 & 0.16 & 0.13 \\
\hline CD at 5\% & 0.003 & 0.003 & 0.001 & 0.002 & 0.42 & 0.34 & 0.18 & 0.15 & 0.48 & 0.40 \\
\hline \multicolumn{11}{|l|}{ Inoculation and vermicompost } \\
\hline $\begin{array}{l}\text { Inoculation (Azotobacter ST3 \&Pseudomonas } \\
\text { P36)+vermicompost @5t/ha }\end{array}$ & 0.259 & 0.249 & 0.102 & 0.097 & 12.52 & 11.29 & 7.44 & 6.11 & 19.96 & 17.40 \\
\hline Inoculation (Azotobacter ST3 \& Pseudomonas P 36) & 0.249 & 0.243 & 0.092 & 0.088 & 11.51 & 10.35 & 6.42 & 5.16 & 17.93 & 15.51 \\
\hline Vermicompost @5t/ha & 0.254 & 0.245 & 0.096 & 0.092 & 11.93 & 10.75 & 6.82 & 5.62 & 18.75 & 16.37 \\
\hline No inoculation & 0.231 & 0.225 & 0.089 & 0.084 & 10.13 & 9.41 & 6.01 & 4.88 & 16.14 & 14.29 \\
\hline SEm \pm & 0.001 & 0.001 & 0.001 & 0.001 & 0.19 & 0.16 & 0.08 & 0.07 & 0.22 & 0.18 \\
\hline CD at $5 \%$ & 0.004 & 0.004 & 0.002 & 0.002 & 0.59 & 0.48 & 0.25 & 0.22 & 0.67 & 0.56 \\
\hline \multicolumn{11}{|l|}{ Fertilizers } \\
\hline $75 \%$ RDF & 0.243 & 0.233 & 0.090 & 0.086 & 10.51 & 9.49 & 6.09 & 4.98 & 16.60 & 14.47 \\
\hline $100 \%$ RDF & 0.249 & 0.236 & 0.095 & 0.091 & 11.78 & 10.47 & 6.80 & 5.51 & 18.57 & 15.98 \\
\hline $125 \%$ RDF & 0.252 & 0.252 & 0.098 & 0.094 & 12.28 & 11.40 & 7.13 & 5.84 & 19.42 & 17.24 \\
\hline SEm \pm & 0.001 & 0.001 & 0.001 & 0.001 & 0.15 & 0.11 & 0.08 & 0.08 & 0.18 & 0.16 \\
\hline CD at $5 \%$ & 0.004 & 0.004 & 0.002 & 0.003 & 0.43 & 0.32 & 0.23 & 0.27 & 0.53 & 0.47 \\
\hline
\end{tabular}


Table.4 Effect of saline water and different nutrient management practices on potassium content and its uptake by wheat crop

\begin{tabular}{|c|c|c|c|c|c|c|c|c|c|c|}
\hline \multirow[t]{2}{*}{ Treatments } & \multicolumn{2}{|c|}{$\begin{array}{c}\text { K content } \\
(\%) \\
\text { in grain }\end{array}$} & \multicolumn{2}{|c|}{$\begin{array}{c}\text { K content } \\
(\%) \\
\text { in straw }\end{array}$} & \multicolumn{2}{|c|}{$\begin{array}{c}\text { K uptake } \\
\text { (kg/ha) } \\
\text { by grain }\end{array}$} & \multicolumn{2}{|c|}{$\begin{array}{c}\text { K uptake } \\
\text { (kg/ha) } \\
\text { by straw }\end{array}$} & \multicolumn{2}{|c|}{$\begin{array}{l}\text { Total K } \\
\text { uptake } \\
\text { (kg/ha) }\end{array}$} \\
\hline & $\begin{array}{c}2011- \\
12\end{array}$ & $\begin{array}{c}2012- \\
13\end{array}$ & $\begin{array}{c}2011- \\
12\end{array}$ & $\begin{array}{c}2012- \\
13\end{array}$ & $\begin{array}{c}2011- \\
12\end{array}$ & $\begin{array}{c}2012- \\
13\end{array}$ & $\begin{array}{c}2011- \\
12\end{array}$ & $\begin{array}{c}2012- \\
13\end{array}$ & $\begin{array}{c}2011- \\
12\end{array}$ & $\begin{array}{c}2012- \\
13\end{array}$ \\
\hline \multicolumn{11}{|l|}{ Quality of irrigation water } \\
\hline Canal water & 0.381 & 0.383 & 0.921 & 0.910 & 19.48 & 17.86 & 70.58 & 60.33 & 90.06 & 78.19 \\
\hline SEm \pm & 0.003 & 0.002 & 0.004 & 0.003 & 0.21 & 0.14 & 0.47 & 0.38 & 0.46 & 0.43 \\
\hline CD at $5 \%$ & 0.008 & 0.006 & 0.013 & 0.008 & 0.63 & 0.42 & 1.44 & 1.15 & 1.39 & 1.31 \\
\hline \multicolumn{11}{|l|}{ Inoculation and vermicompost } \\
\hline $\begin{array}{l}\text { Inoculation (Azotobacter ST3 \&Pseudomonas P 36) } \\
\text { + vermicompost @5t/ha }\end{array}$ & 0.389 & 0.402 & 0.934 & 0.923 & 18.75 & 18.18 & 67.75 & 57.96 & 86.50 & 76.14 \\
\hline SEm \pm & 0.004 & 0.003 & 0.006 & 0.004 & 0.29 & 0.20 & 0.67 & 0.53 & 0.65 & 0.61 \\
\hline CD at 5\% & 0.011 & 0.010 & 0.019 & 0.012 & 0.89 & 0.60 & 2.04 & 1.62 & 1.97 & 1.85 \\
\hline \multicolumn{11}{|l|}{ Fertilizers } \\
\hline $75 \%$ RDF & 0.364 & 0.363 & 0.895 & 0.833 & 15.66 & 14.71 & 59.80 & 50.24 & 75.46 & 64.95 \\
\hline $100 \% \mathrm{RDF}$ & 0.368 & 0.370 & 0.896 & 0.847 & 17.32 & 16.41 & 63.62 & 53.32 & 80.93 & 69.73 \\
\hline $125 \%$ RDF & 0.375 & 0.377 & 0.904 & 0.852 & 18.16 & 17.04 & 65.26 & 54.98 & 83.42 & 72.02 \\
\hline SEm \pm & 0.003 & 0.002 & 0.005 & 0.005 & 0.23 & 0.17 & 0.61 & 0.77 & 0.70 & 0.80 \\
\hline CD at $5 \%$ & NS & NS & NS & NS & 0.65 & 0.48 & 1.75 & 2.23 & 2.03 & 2.31 \\
\hline
\end{tabular}


The solubilizing action of organic acids produced during decomposition of vermicompost might have increased the release of native $\mathrm{P}$, stimulated microbial growth in soil and favoured root growth which had finally led to increased P uptake by wheat. The results are in agreement with the findings of Laghari et al., (2010), Devi et al., (2011), Sharma et al., (2013) and Ram et al., (2014).

Among various fertilizer treatments, $125 \%$ RDF treatment recorded maximum phosphorous content in grain and straw followed by $100 \%$ RDF and minimum was observed in $75 \%$ RDF during both the years. Similar trend was observed for P uptake by grain, $\mathrm{P}$ uptake by straw and total uptake. The results are in agreement with the findings of Laghari et al., (2010), Chesti et al., (2013) and Sharma et al., (2013).

Potassium content (\%) and its uptake (kg/ha) by grain and straw

Potassium content in grain and straw, $\mathrm{K}$ uptake by grain and straw and total $\mathrm{K}$ uptake also varied significantly among quality of irrigation water, inoculation and vermicompost and different levels of fertilizer treatments during both the years (Table 4).

Under quality of irrigation water, canal water treatment resulted in significantly higher $\mathrm{K}$ content ingrain $(0.381,0.383 \%)$ as compared to saline water $(0.357,0.356 \%)$ during 2011 12 and 2012-13, respectively. Similar trend was observed for $\mathrm{K}$ content in straw, $\mathrm{K}$ uptake by grain and straw and total $\mathrm{K}$ uptake during both the years of study. The results of present studies are in conformity with Hussain et al., (2014) and Yadav et al., (2015). The decrease in $\mathrm{K}$ content in grain and straw is due to suppressed $\mathrm{K}$ uptake by increased $\mathrm{Na}^{+}$ concentration in soil solution due to saline water application (Sharma, 2003).
Among the inoculation and vermicompost treatments, Azotobacter ST3 \&Pseudomonas P36 + vermicompost @5 t/ha treatment resulted in significantly higher $\mathrm{K}$ content in grain and straw, followed by vermicompost @ 5t/ha during both the years. Similar trend was observed for K uptake by grain and straw and total uptake. The increased uptake of $\mathrm{K}$ by wheat may be ascribed to the release of $\mathrm{K}$ from the $\mathrm{K}$ bearing minerals by complexing agents and organic acids produced during decomposition of organic resources. The results are in agreement with the findings of Devi et al., (2011), Sharma et al., (2013) and Ram et al., (2014).

The data also revealed that various fertilizer treatments have no significant effect on potassium content in grain and straw during both the years. In case of grain, straw and total potassium uptake, significantly higher values were recorded with application of $125 \%$ RDF followed by 100 and $75 \%$ RDF treatments during both the years. The results are in agreement with the findings of Laghari et al., (2010). Since, potassium was not added through recommended dose of fertilizer, nonsignificant effect was observed on $\mathrm{K}$ content in grain and straw. Based on two years of investigation, it is concluded that application of vermicompost along with biofertilizers and chemical fertilizers improved the protein content, content and uptake of nutrients by wheat, more pronounced in non-saline water than saline water.

\section{References}

Alam, S.M. (1999). Nutrient uptake by plants under stress conditions. In: Handbook of plant and crop stress, (Ed.) Pssarakli, M. New York: Marcel Dekker, pp. 285313.

Ashraf, M., and Harris, P. J. C. (2004). Potential biochemical indicators of 
salinity tolerance in plants. Plant Sci., 166: 3-16.

Axford, D.W.E., Mc-Dermott, E.E., and Redman, D.G. (1979). Note on SDSsedimentation test and bread making quality. Comparison with pelshenke and zeleny-tests. Cereal Chem., 56: 582584.

Bano, A. and Fatima, M. (2009).Salt tolerance in Zea mays (L.) following inoculation with Rhizobium and Pseudomonas. Biol. \& Fert. Soils, 45: 405-413.

Bulut, S. (2013). Evaluation of yield and quality parameters of phosphoroussolubilizing and $\mathrm{N}$-fixing bacteria inoculated in wheat (Triticum aestivum L.). Turk. J. Agric. For., 37: 545-554.

Chesti, M.H., Kohli, A. and Sharma, A.K. (2013).Effect of integrated nutrient management on yield of and nutrient uptake by wheat (Triticum aestivum) and soil properties under intermediate zone of Jammu and Kashmir. J. Ind. Soc. Soil Sci., 61(1): 1-6.

Datta, J.K., Nag, S., Banerjee, A. and Mondal, N.K. (2009). Impact of salt stress on five varieties of wheat (Triticum aestivum L.) cultivars under laboratory condition. J. Appl. Sci. Environ. Manage, 13(3): 93-97.

Davari, M.R., Sharma, S.N. and Mirzakhani, M. (2012). The effects of combinations of organic materials and biofertilizers on productivity, grain quality, nutrient uptake and economics of wheat in organic farming. J. Org. Syst., 7(2): 2635 .

Devi, K.N., Singh, M.S., Singh, N.G. and Athokpam, H.S. (2011).Effect of integrated nutrient management on growth and yield of wheat (Triticum aestivum L.) J. Crop \& Weed, 7(2): 2327.

Fana, G., Deressa, H., Dargie, R., Bogale, M., Mehadi, S. and Getachew, F. (2012). Grain hardness, hectolitre weight, nitrogen and phosphorus concentrations of durum wheat (Triticum turgidum L. var. Durum) as influenced by nitrogen and phosphorus fertilization. World Appl. Sci. J., 20(10): 1322-1327.

Francois, L.E., Mass, E.V., Donovan, T.J. and Young, V.L. (1986). Effect of salinity on grain yield and quality, vegetative growth and germination of semi-dwarf and durum wheat. Agron. J., 78:10531058.

Hussain, R.A., Ahmad, R., Waraich, A.A. and Nawaz, F. (2014). Nutrient uptake, water relations and yield performance of different wheat cultivars (Triticum aestivum L.) under salinity stress. J. Plant Nutri., 38(13): 2139-2149.

Hussain, S., Sharif, M., Khan, S., Wahid, F., Nihar, H., Ahmad, W., Khan, I., Haider, N. and Yaseen, T. (2016). Vermicompost and mycorrhiza effect on yield and phosphorus uptake of wheat crop. Sarhad J. Agric., 32(4): 372-381.

Joppa, L.R. (1975). Genetic engineering and durum quality. MaCorony J., 57: 8.

Knapowski, T., Ralcewicz, M., Barczak, B. and Kozera, W. (2009). Effect of nitrogen and zinc fertilizing on breadmaking quality of spring triticale cultivated in Notec Valley. Polish J. of Environ. Stud., 18(2): 227-233.

Koenig, R.A. and Johnson, C.R. (1942).Colorimetric determination of $\mathrm{P}$ in biological materials. Ind. Eng. Chem. Anal., 14: 155-156.

Konvalina, P., Stenho, Z. and Moudry, J. (2009). The critical point of conventionally bred soft wheat varieties in organic farming systems. Agron. Res., 7(2): 801-810.

Kumar, R. (2000). Effect of organic and inorganic fertilizer levels in normal and saline soil on wheat. M.Sc. thesis submitted to Chaudhary Charan Singh Haryana Agricultural University, Hisar. 
Laghari, G.M., Oad, F.C., Tunio, S., Gandahi, A.W., Siddiqui, M.H., Jagirani, A.W. and Oad, S.M. (2010). Growth, yield and nutrient uptake of various wheat cultivars under different fertilizer regimes. Sarhad J. Agric., 26(4): 489497.

Lindner, R.C. (1944).Rapid analytical method for some of the more common inorganic constituents of plant tissues. Plant Physiol., 19: 76-89.

Mansour, M. M. F. (2000). Nitrogen containing compounds and adaptation of plants to salinity stress. Biologia Plantarum, 43: 491-500.

Misra, B.K. and Gupta, R.K. (1995). Quality report (1994-1995) presented at the $34^{\text {th }}$ All India Wheat Workshop held at Dharwad.

Naserian, B., Zamani, M. and Vedadi, C. (2014). Effects of drought and salinity as abiotic stresses on some qualitative traits of Iranian wheat genotypes. Romanian Biotechnol. Lett., 19(2): 9212-9221.

Ram, M., Davari, M.R. and Sharma, S.N. (2014).Direct, residual and cumulative effects of organic manures and biofertilizers on yields, NPK uptake, grain quality and economics of wheat (Triticum aestivum L.) under organic farming of rice-wheat cropping system. J. Org. Sys., 9(1): 16-30.

Saleh, A.L., Abdel-Kader, A.A. and Alva, A.K. (2015). Response of two wheat cultivars to supplemental nitrogen under different salinity stress. J.Agril. Sci., 7(6): 14-19.
Sharma, G.D., Thakur, R., Raj, S., Kauraw, D.L. and Kulhare, P.S. (2013).Impact of integrated nutrient management on yield, nutrient uptake, protein content of wheat (Triticum aestivum L.) and soil fertility in a typic Haplustert. The Bioscan, 8(4): 1159-1164.

Sharma, R. (2003). Effect of salinity and nitrogen on yield and nutrient uptake of wheat cultivars. M.Sc. thesis submitted to Chaudhary Charan Singh Haryana Agricultural University, Hisar.

Shishehbor, M., Madani, H. and Ardakani, M.R. (2013).Effect of vermicompost and biofertilizers onyield and yield components of common millet (Panicum miliaceum). Ann. Biol. Res., 4(2):174-180.

Singh, G. and Paliwal, S.C. (1986).Physicochemical, milling and bread making quality of the varieties of durum wheat. Bull. Grain Technol., 24: 73-76.

Tammam, A.A., Alhamd, M.F.A. and Hemeda, M.M. (2008).Study of salt tolerance in wheat (Triticum aestivum L.) cultivar Banysoif 1. Austral. J. Crop Sci., 1(3): 115-125.

Yadav, A.K., Yadav, P.K., Phogat, V., Tikkoo, A. and Yadav, S.S. (2015). Effect of saline water irrigation on the yield and mineral composition of crops in rice-wheat cropping system. J. Ind. Soc. Soil Sci., 63(3): 276-282.

Zheng, Y., Xu, X., Li, Z. and Yang, X. (2009).Differential responses of grain yield and quality to salinity between wheat cultivars. Seeds Sci. \& Biotechnol, 3: 40-43.

\section{How to cite this article:}

Sunil Kumar, Satyavan, Ramprakash and Devender Sihag. 2018. Quality Parameters, Nutrient Content and Uptake as Influenced by INM in Wheat (Triticum aestivum L.) under Saline and Non-Saline Irrigation Water. Int.J.Curr.Microbiol.App.Sci. 7(05): 607-617. doi: https://doi.org/10.20546/ijcmas.2018.705.075 